\title{
WOMEN LEADERSHIP PARADIGM: PRO AND CONTRA ON WOMEN AS LEADERS IN VARIOUS VIEWS
}

\author{
Eviatiwi Kusumaningtyas Sugyanto ${ }^{1}$
}

Faculty of Economics, Universitas Semarang

\begin{abstract}
The number of female workers is increasing and its role in leadership is giving its own perspective on the topic of women leadership. Pro and contra phenomenon related to women leadership still exist in the society. In addition to explain the paradigm of woman leadership, this study also explains the pro and contra of women leadership from various perspectives and provides an overview of how the pro and contra emerge. The method that was used in this study is literature study from the Al-Quran, books, journals and studies. The findings of this study shows that women leadership style leads to transformational, democratic, collaborative styles and have high relational value. Leadership is left to follow one's worth and ability from either men or women. If someone meets the requirements and deserves to be a leader even though from the women's group this remains true. The emergence of pro and contra is based on different point of views; every point of view has different concepts which lead to different practices. The results of an interpretation are not only come from the methods and approaches used, but are also influenced by their socio-cultural and ideological conditions.
\end{abstract}

Keywords: Women Leadership, Pro \& Contra.

${ }^{1}$ eviatiwisugiyanto@usm.ac.id; Faculty of Economics, Universitas Semarang 


\section{INTRODUCTION}

The increasing number of women workers and their role in leadership are giving a separate picture on the topic of women leadership. In the political arena as well as representative organizations, the role of women as a leader also increased. History has also recorded several successful women who became leader. The role of women in organizations is like two sides of a coin which is very dilemmatic. On the one hand, women struggle is to realize and maximize their ability, so that rights and recognition can be obtained. On the other hand, there are many parties who are still debating, especially cornering the position of women (Meizara, 2016). In an organization the dominance of men as a leader is indeed very strong, even though women have shown their potential that is not inferior to men.

The world view of women leadership has changed, including Egypt, with its majority of Muslim population, which at first strongly opposed women leadership. But in its development the Egyptian government accepted the presence of women in the political arena. Furthermore, people in Pakistan, used to do not accept the participation of women in various social activities. Their public perception began to change with the election of Benazir Bhutto as Prime Minister. As well as in Bangladesh, women are marginalized, lack of appreciation. Their point of view changed after Khalidah Ahmad was appointed as Prime Minister. Previously women were seen as being inferior and subordinate to men, which led them to a marginal position in community of life. Nowadays women have become male partners whish have equal position without discrimination against either party (Salenda, 2012).

Women leadership in Indonesia, especially as a leader of the State still become a controversial issue although it is still a pro and contra, the role of women as leaders in Indonesia shows positive development. In Indonesia, there were many women leaders who emerged, including Megawati Soekarno Putri as the 5th President of Indonesia, Sri Mulayani and Khofifah Indar as Ministers, Mrs. Risma as Mayor of Surabaya and much more. The phenomenon of women in the modern era, women have appeared to be leaders by occupying various important positions both in large (public), or small (domestic) societies (Tohet, 2018). It shows their ability to be leaders and equal to men. 
Women leadership has been widely discussed and has become a debate related to issues of gender equality. The debate continues to emerge because gender is seen from various perspectives, motives, and interests (Yusuf, 2015). Women are an integral part of society, where women are partners and equal with men in various aspects of life (Novianti, 2008). The debate over women leadership in the public brings pro and contra to the paradigm of women leadership. In addition to explain the paradigm of woman leadership, this study also explains the pro and contra of women leadership from various perspectives and provides an overview of how the pro and contra emerge.

\section{METHOD, DATA AND ANALYSIS}

The type of this study is library research, with descriptive analytic methods. Data in this study are obtained from Qur'an, books, journals and other study related to the research topic.

\section{RESULTS AND DISCUSSION}

\section{A. Paradigm of Women Leadership}

The definitions of leadership in some literatures agree that it is related to the process of someone who tries to influence a group or followers to achieve certain goals (Hassan, 2008). Whereas women leadership are defined as the ability to move, influence, motivate, invite, direct, advise, guide, order, prohibit and even punish (if necessary), and foster with the intention that humans want to work in order to achieve common goals effectively and efficiently which is carried out by a woman (Rohmiyati, 2016).

Women leadership leads to human feminine traits. Feminine is etymologically derived from Latin, namely femina which is translated in English as feminine, meaning that it has the characteristics as a woman. The combination of leadership and feminist traits or characteristics gave rise to a concept that was given the name "feminist leadership". Feminists refer to attitudes, while leadership refers to actions, so feminist leadership can be interpreted as actions carried out by leaders based on 
feminist traits. According to Chin (2004), feminist leadership is women leadership style based on characteristics or attributes of "feminist".

Smit (2017), explains the five attribute of "feminist" consist of: 1) care, defined as a moral commitment to act on behalf of others, care exists in relational leadership that shows concern and compassion for all colleagues. 2) Vision, the ability to formulate and articulate original ideas through processes facilitated by encouragement. Visionary leaders create trusting, collaborative and participatory work environment between colleagues. 3) Collaboration. The ability to work in a group, support group members, and create an energetic environment. Collaboration involves inclusiveness, sharing of idea, connectedness and cooperation. 4) Courage, the ability to move forward, look for new ideas in the world of practice. This also includes the willingness to take risks for the progress of the team and individuals. 5) Intuition, the ability to give equal weight to experiences and abstractions, thoughts and heart. Intuition act as the initiator of the capacity of mind and heart that cannot be separated from the relational leadership approach.

Transformational and transactional leadership has become a popular theme in leadership styles. There are also autocratic and democratic leadership styles. Several studies have shown differences in leadership styles between women and men. Female leaders tend to be more relationship-oriented and democratic, whereas male leaders are more likely to be task-oriented and motivated (Hassan, 2008). Furthermore, based on Rosener in Hassan (2008), states that female leaders are more likely to lead to a transformational style compared to men. This argument based on that transformational emphasized on the nurturing their fellow and the process of socialization, where the quality of care for women is better than men. Women leadership is more related to a holistic approach and "bottom-up" in developing society. This approach has greater success and impact on community development compared to the approach "top-down" which commonly used by male leaders.

Some leadership literature approaches emphasize the characteristics that exist in a leader such as the characteristics of a leader, expertise or leadership style. Feminists put more emphasis on planning and organizing work using an empathy approach rather than emphasizing "having to win at all costs" when compared to men, besides explaining that women prefer to use parenting patterns to engage, communicate and 
lead (Chin, 2007) . Furthermore Chin (2007) explains that feminist leadership or known as shared leadership places more emphasis on collaborative style. In principle, all members will be involved in planning and decision making so that they reach their decision. Use Collaborative style is intended to create an equal environment between leaders and members.

The results of Eagly and Carli's study (2003), show that women leadership is more effectively implemented in areas with low masculinity conditions. The study findings include: 1) women are less effective than men as long as the leadership position is dominated by men; 2) women are less effective compared to men where there is an increasing proportion of male subordinates; 3) women are less effective than men if the greater proportion of men among leaders effectiveness assessors, 4) women are substantially less effective than men in military organizations, and slightly more effective than men in education, government organizations, and social services; 5 ) women are relatively more effective than men, in middle level leadership positions.

Gender differences provide a different picture of leadership between male and women leadership styles. Men tend to have a masculine leadership style while women tend to have a feminism leadership style (Situmorang, 2011). Feminine and masculine characteristic were presented in table 1.

Table 1

Feminine and Masculine characteristic

\begin{tabular}{ll}
\hline Feminim & Maskulin \\
\hline Not aggresive & Aggresive \\
Dependen & Independent not Emotional \\
Emotional & Very Objective \\
Very subjective & Not easily Influenced \\
Easily influenced & Active \\
Passive & Very Competitive \\
Uncompetitive & Easily to take decision Independent \\
Hard to take decision & Hard to get offended Like to \\
Dependent & Speculate \\
Easily get offended & \\
hate Speculation & \\
\hline
\end{tabular}




\begin{tabular}{ll}
\hline Lack of & High confidence \\
confidence & Do not require scurity \\
Require security & Do not concern on his \\
Very concern & apparance \\
on his & \\
apparance & \\
\hline
\end{tabular}

Loden in Situmorang (2011), explained that masculine leadership style has competitive characteristics, hierarchical authority, high control for leaders, not emotional, and analysis in overcoming problems, while feminine leadership has the characteristics of cooperative, collaboration, low control for leaders, and overcome problems based on intuition and empathy. Smit (2017) adds that the value of relational relationships of women is higher than men, women leadership is documented with high relational aspects, communicative, teamwork, and collaboration also community connections.

Miller in Lanza (1997) notes that men and women differ in their views of power, the masculine model shows the existence of "power-grabbing", namely the struggle for power and the desire to master one another. On the other hand, Feminine model is "power sharing" which put on forward to the power of distribution. The characteristics of power theory are awareness, choice, freedom to act and involvement to create change. These characteristics are in line with the basic concepts of feminist ideology that seek to find their freedom (Lanza, 1997).

The paradigm is feminist also often associated with religious perspectives, especially in Islam. The value of Islam originated from the Qur'an and Hadith. In connection with the paradigm feminist that is closely related to women's issues, Amina Wadud a feminist and professor of Islamic Studies at Virginia Commonwealth University uses two methodological approaches in the interpretation of the Qur;an known as "Hermeneutics of Monotheism" (Hakim, 2017): first, the approach of normative idealism means that the feminist theology that is about to be formulated refers to norms that originate from the ideal teachings of Islam. In this approach he sees how the Koran outlines its basic principles which are normative in nature. For 
example, how should the woman according to the Qur'an both her behavior related to her Lord and to others and also with herself. Second, the empirical historical approach is that it looks at how the normative ideal of the Qur'an is; it looks at the historical reality of the condition of women in Islamic society. So that on the one hand he gets a theoretical picture that is normative idealist about the view of the Qur'an towards women who are historical and empirical in society.

\section{B. Pro Woman Leadership}

From Islamic point of view, explains that the Qur'an has documented the existence of women leadership in Surat al-Naml: 23-44 which shows the leadership figure of Queen Balqis. The ideal characteristics of women leadership in Surat alNaml: 23-44 are wise, democratic, diplomatic, peace-loving, intelligent, and conscientious (Nurbaiti \& Syafieh, 2018). The leadership of the queen of Balqis is democratic, by not deciding matters of her own will but rather by considering the opinions of others who are involved (Tohet, 2018). This shows that Islam provides opportunities for women to become leaders and perform according to their expertise. In Surat al-Naml specifically told about the figure of a female leader who can change the way people think so they will not discriminate against women leadership. If there are women who have good leadership characteristics, there is no harm in being a leader as long as they do not forget their nature as mothers and wives and do not deviate from religious norms (Nurbaiti \& Syafieh, 2018).

Islamic feminist figures say that there is no legitimacy of subordinate women below men, there is a normative system of division of labor in both the family and society. There are no values in in Islam which teach to prevents women from working and expands their public work. In the Al-Maidah verse 55 which also implies four criteria for leaders, the letter does not address the issue of the sexes of men and women to become leaders (Ilyas, 2002). The four criteria are 1) Believing in Allah SWT, 2) Establishing Salat, 3) Paying Zakat, 4) Always submitting and obeying Allah SWT. Based on Al-Maidah's letter 55 there is no prohibition for a woman to become a leader. The views of the Bugis clerics explain that the Al-Nisa letter descended in the context of family leadership rather than other domains, this means that women have 
the opportunity in the public sphere to become leaders as long as they have the necessary requirements (Yusuf, 2015).

In leadership, the value of which is considered the most dominant is personality qualities which include the ability, capacity, faculty, and skills, there is no link of gender in leadership, which means that there is equality between men and women to become leaders (Novianti, 2008). Biological differences do not mean causing social inequalities in life.

A Study by Muller and Cocotas in 1988, Supports other feminine leadership styles, they examined the professional experience of prominent women leaders in Washington DC. They mark their leadership management style as participatory, people-oriented, factual, competent and politically savvy. The leadership style combines a collaborative personality to manage people with an objective and rational approach (Lanza, 1997).

Cantor and Bernay in Denmark (1993), these two psychodynamic practitioners interviewed 25 prominent women politicians in America. They hope to hear how difficult it is to be a woman in achieving the political position that is the realm of men. The writers were surprised by the answer that there were no obstacles that prevented their progress. All of that is related to confidence of their ability to be successful. The results of the interview by Cantor and Bernay which creat "Leadership Equation" with the following formulation

\section{Leadership $=$ Self-Competent + Creative Aggression + Woman Power}

Self-Competent implies a strong sense of self and the ability to see possibilities within any obstacles. Creative aggression includes initiative, leading people, dialogue, even if it is being underestimated. Women power is a combination of masculine and feminine qualities, combining power with care. This includes the ability to make a difference in society for something better "the ability to get things done". Furthermore Cantor and Bernay gave a message to all women who have aspirations to become leaders, the message contains 5 basic leadership secrets, include: (a) You are a loved and special person, (b) You can do anything You want, (c) you can be brave and take the risks, (d) you can use and enjoy your Creative Aggression, and (e) you have the right to dream of greatness. From this message, it is implied that every woman has the 
right to dream of greatness, especially to become a great leader. Quraisy Syihab in (Tohet, 2018) added that the leadership of the public was handed over to follow the worthiness and ability of a person, both men and women so, when someone meets the requirements and deserves to be a leader even though from the women's group this remains true.

According to Tjokroaminoto in (Rahim, 2016) the causes of low participation of women and tend to occupy a backward position are 1) The existence of masculine / feminine dichotomy of human roles as a result of biological determination often results in the process of marginalization of women; 2) Existence the dichotomy of public roles / domestic roles rooted in the syndrome that "women's role is at home" in turn preserves the division between productive and reproductive functions between men and women; 3) The concept of a "double workload" that preserves the insight that women's duties primarily are at home as housewives, tend to experience the process of actualizing the full potential of women; 4) The existence of a syndrome of subordination and the marginal role of women has preserved the insight that the role and function of women in society is secondary.

\section{Contra to Women Leadership}

Women leadership is disputed among commentators. Yusuf (2015) explains that the basis for the rejection of women leadership by some people is the Qur'an, Surah al-Nisa / 4: 34 with the translation: "... men are leaders for women, because Allah has exalted some of them (men) for another part (women), and because they (men) have spent part of their property ... ". The male leadership in this verse then becomes the legitimacy of the men's right to lead in any field including in prayer so that Imamat becomes a male privilege and authority. Consequently, women are only entitled to be followers in all aspects of their lives (Anshori, 2015).

The discussion of women as leaders comes from evaluating stereotypes for a group. The conclusion of this stereotype produces prejudices for individuals in the group. Mismatch of stereotypes with related attributes tends to produce discrimination (Eagly \& Carli, 2003). The mismatch between expectations about women and expectations about leaders underlines prejudice against women's leadership. 
The stereotype of the role of women in the public has occurred long before Islam came, namely in the past Arabian peninsula which considers women as second class humans after men (Fadilah \& Wahyudi, 2018). Because the law in force at this time is a combination of the inheritance of Mesopotamian values and religious values taken from the scriptures, as in the Old Testament, the new covenant, especially in the chapters of the book of events and in more detail in the Talmud. All information in the book seems to match women of the second gender who must submit to male authority.

Sayid Qutb in Hakim (2017) explained that men also have a specificity that is equipped with courage, their feelings are not too sensitive and reactive and always use consideration and thought before act and react. So it is these special qualities that make it more able to carry out leadership and more worthy of cultivating leadership. Some groups reject women leadership based on the history of da'wah, the argument is from the time of the Prophet Adam to the Prophet Muhammad and the leaders chosen by the ulama are all men, they also hold to the hadith which states "will not be lucky or successful a people who surrender its affairs to women "(Adnan, 2016)

Sabuni, Thaba'thabai in (Ilyas, 2002) explained that men have intellectual advantages (giving priority to reason rather than feeling) compared to women, because it is more stoic and resistant in facing challenges and distress, whereas women are superior in the nature of tenderness and smoothness. The strong views that women use their feelings rather than rational thought imply that women do not fit into hard work fields, including in this case being leaders in the political field (Hamka, 2013). The majority of organizational structure, culture and daily practice prove that the "ideal employee" and leader, the ideal is better suited to a rational figure that is more directed at masculinity than femininity (Ford, 2005).

Ford (2005) further explains that the behavior that is considered appropriate to be a leader in the present is masculinity with a rational, measurable, objective and competitive image. While women with a "feminist" characterisctic is caring and sharing are more appropriate for domestic area, reproduction of homes and families. Visser in Situmorang (2011) explains that feminine style is inherent in family-oriented leadeship while masculine style is more career-oriented leadership. Men and women have the privileges of each, but the privileges of men are more suitable for the leadership task than the privileges that women have. On the other hand, the privileges 
that women have are more supportive of their duties as givers of peace and calm to men and more supportive of their functions in educating and raising their children (Tohet, 2018).

The cultural text explains that effective leadership is identified by the attributes and characteristics of masculinity, while less effective leadership is identified by the attributes and nature of femininity (Oplatka, 2016). Another general explanation for women's underrepresentation in leadership refers to the structure of relationships and power that is dominated by men,

\section{CONCLUSIONS}

Issues regarding to controversy and differences of opinion related to women leadership are caused by different point of views. For example, the point of views of the Bugis clerics explain that the Surah Al-Nisa descended in the context of family leadership rather than other domains, it means that women have the opportunity in the public to become leaders as long as they have the necessary requirements (Yusuf, 2015), but some state that the Surah Al -Nisa becomes the legitimacy of men's rights to lead in any field which explained that the interpretations derived from religious texts with the hermeneutic approach are relative and not truly objective.

Mas'ud (2015) explained that the way a person thinks and acts must be based on the worldview they followed, then concepts and theories determine the practice that is carried out. The same thing to the pro and contra of women leadership. The emergence of pro and contra is based on different views; these different views will produce different concepts that will lead to different practices.

Source: Mas'ud (2015)

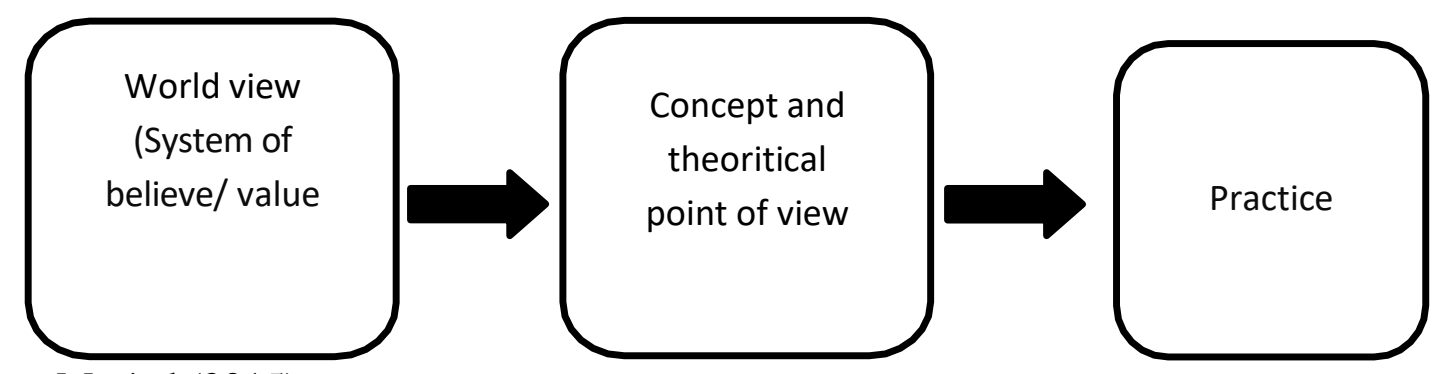

Figure 1. The relationship between the World View, Concepts and Theories, and Practice 
Controversy that arises regarding the discrimination on the rejection against Women Leadership, it is not originate from these texts but it is the disclaimer itself that ultimately causes debate. Someone's interpretation comes from the view of life held by that person. The results of an interpretation are not only born from the methods and approaches used by experts, but are also influenced by their sociocultural and ideological conditions (Tohet, 2018). Interpretation is seen as a product of human mind that is relative, contextual, temporal and personal (Hakim, 2017). These interpretations often do not have a proper religious point of view, but rather focus on how to legalize the opinions they had. Amina Wadud, said that the verses and principles of the Qur'an did not change, what was changed was the capacity of understanding and reflecting on these verses in a society. Whether or not a woman becomes a leader depends on her expertise, the behavior she has is not based on gender and is free of gender. Masculinity and femininity are only limited to stereotypes embedded for certain groups. Characteristics of masculinity and femininity can be exchanged, there are women who have masculine characteristic and there are also men who have feminine characteristic (Situmorang, 2011). Leadership is seen from individual character, it is not the result from stereotypes or assumptions of the products of human reason.

\section{REFERENCES}

Adnan, A. (2016). Pandangan Kritis terhadap Pendekatan Feminis. El-Hikmah, 8(3), 8094.

Anshori, M. A. (2015). Perempuan: Perspektif Filsafat, Tasawuf dan Fiqih. Al-Adyan: Jurnal Studi Lintas Agama, 10(1), 1-18.

Chin, J., L. (2004). 2003 Division 35 Presidential Address: Feminist Leadership: Feminist Vision and Diverse Voice Pyshocology of Women Quartely, 28, 1-8.

Chin, J., L. (2007). Overview: Women and Leadership: Transforming Visions and Diverse Voices. Retrieved from

Denmark, F., L. (1993). Women, Leadership, and Empowerment. Psychology of Women Quarterly, 17, 343-356.

Eagly, A. H., \& Carli, L. L. (2003). The female leadership advantage: An evaluation of the evidence. The Leadership Quarterly, 14(6), 807-834. doi:10.1016/j.leaqua.2003.09.004

Fadilah, N., \& Wahyudi, W. (2018). Tinjauan Hermeneutis Terhadap Hadis Kepemimpinan Perempuan Dalam Islam. FIKRI : Jurnal Kajian Agama, Sosial dan Budaya. doi:10.25217/jf.v3i2.350 
Ford, J. (2005). Examining leadership through critical feminist readings. J Health Organ Manag, 19(3), 236-251. doi:10.1108/14777260510608961

Hakim, L. (2017). Mis-Interpretasi Ayat Kepemimpinan Laki-Laki Atas Perempuan (Kritik Terhadap Tafsīr Feminis). Studia Quranika, 1(2). doi:10.21111/studiquran.v1i2.848

Hamka, H. (2013). Kepemimpinan Perempuan dalam Era Modern. Al Qalam, 19(1), 107-116.

Hassan, Z. S., Abu Daud. (2008). Women Leadership and Community Development. European Journal of Scientific Research, 23(3), 361-372.

Ilyas, Y. (2002). Problem Kepemimpinan Perempuan dalam Islam. Tajrih, 3, 64-73.

Lanza, M. L. (1997). Feminist leadership through total quality management. Health Care Women Int, 18(1), 95-106. doi:10.1080/07399339709516262

Mas'ud, Fuad (2015). Menggugat Manajemen Barat, Mengungkap Pandangan Dunia Yang Tersembuyi yang Menjadi Dasar Konsep, Teori dan Praktek Manajemen Barat. In: Semarang: Badan Penerbit Universitas Diponogoro.

Meizara, E. D., Puspita, Basti. (2016). Analisis Kompetensi Kepemimpinan Wanita. Jurnal Imiah Psikologi Terapan, 4(2), 175-181.

Novianti, I. (2008). Dilema Kepemimpinan Perempuan dalam Islam Jurnal Studi Gender dan Anak, 3(2), 255-261.

Nurbaiti, N., \& Syafieh, S. (2018). Potret Karakteristik Kepemimpinan Perempuan (Analisis Semiotika Surat Al-Naml: 23-44). JURNAL At-Tibyan: Jurnal Ilmu Alquran dan Tafsir, 3(1). doi:10.32505/tibyan.v3i1.477

Oplatka, I. L., Rachel Hertz. (2016). Women Principals in a Multicultural Society_New Insights into Feminist Educational Leadership: Sense Publisher.

Rahim, A. (2016). Peran Kepemimpinan Perempuan dalam Perspektif Gender. AlMaiyyah, 9(2), 268-295.

Rohmiyati, F. N. (2016). Hakikat Kepemimpinan Perempuan: Sebuah Refleksi Sejarah. An-Nisa', 8(1).

Salenda, K. (2012). Kepemimpinan Perempuan dalam Perspektif Islam. Al-Risalah, 12(2), 369-378.

Situmorang, N., Z. (2011). Gaya Kepemimpinan Perempuan. Proceeding PESAT (Psikologi, Ekonomi, Sastra, Arsitektur dan Sipil), 4, 129-135.

Smit, B. (2017). Female Leadership in a Rural School: A Feminist Perspective. Studies of Tribes and Tribals, 11(1), 89-96. doi:10.1080/0972639x.2013.11886670

Tohet, M., \& Maulidia, L. (2018). Kepemimpinan Perempuan Perspektif Mufassir Nusantara. Jurnal Islam Nusantara,, 2(2), 211-231.

Yusuf, M. (2015). Kepemimpinan Perempuan dalam Perspektif Kearifan Lokal: Pemikiran Ulama Bugis dan Budaya Bugis. Journal of Social Science and Religion, 22(1), 69-81. 